\title{
Studies on the preparation and the photoelectrochemical properties of the nanoporous titania films attached with and without photosensitizer TCPP
}

\author{
YUN-LAN GONG*, FEI-HUI LI, FEI LU and CHANG DAI \\ Department of Applied Chemistry, College of Science, Tianjin University of Commerce, Tianjin 300134, China
}

MS received 2 December 2014; accepted 30 March 2015

\begin{abstract}
Fabrication of $\mathrm{TiO}_{2}$ nanoporous films was carried out by anodic oxidation using two-step voltage mode while the subsequent attaching of the photosensitizer 5,10,15,20-tetra(4-carboxyphenyl) porphyrin (TCPP) on the prepared $\mathrm{TiO}_{2}$ nanoporous films was carried out by the electrochemical method. Photoelectrochemical properties of $\mathrm{TiO}_{2}$ nanoporous films attached with and without photosensitizer TCPP were analysed by fluorescence spectroscopy and electrochemical test. Effects of process parameters on the photoelectrochemical properties of $\mathrm{TiO}_{2}$ nanoporous films were also investigated. The optimized process parameters for the preparation of $\mathrm{TiO}_{2}$ nanoporous films with the best photoelectrochemical property can be concluded as follows: oxidation potentials is 70-140 V, oxidation temperature is $25^{\circ} \mathrm{C}, \mathrm{H}_{2} \mathrm{SO}_{4}$ electrolyte concentration is $0.5 \mathrm{~mol} \mathrm{I}^{-1}$ and oxidation time is $60 \mathrm{~min}$. The results also show that attaching of the photosensitizer $\mathrm{TCPP}$ on the $\mathrm{TiO}_{2}$ nanoporous films can indeed improve the properties of $\mathrm{TiO}_{2}$ nanoporous films, and the optimized attaching temperature and attaching voltage are $25^{\circ} \mathrm{C}$ and $60 \mathrm{~V}$, respectively.
\end{abstract}

Keywords. $\mathrm{TiO}_{2}$; photosensitizer; nanoporous films; anodic oxidation; TCPP; electrochemical attaching method.

\section{Introduction}

In recent years, metal oxide $\mathrm{TiO}_{2}$ has been widely studied for its rich source, low cost, environment friendly and chemical stability. Due to its high photocatalytic activity, $\mathrm{TiO}_{2}$ thin film plays an important role in photovoltaic devices. However, $\mathrm{TiO}_{2}$ is active only under ultraviolet light irradiation due to its wide band gap energy, which reduces its utilization ratio of solar energy and thus limits its application in solar cell. Since the spectral response of $\mathrm{TiO}_{2}$ can move to visible region after with the reduction of dimensions or by sensitizing $\mathrm{TiO}_{2}$ with proper photosensitizer which transition energy matches well with nano-structure $\mathrm{TiO}_{2},{ }^{1-3}$ the preparation of $\mathrm{TiO}_{2}$ materials with nanometer size, such as $\mathrm{TiO}_{2}$ nanoporous films, and $\mathrm{TiO}_{2}$ materials sensitized with photosensitizer have attracted enormous attention.

In recent times, porphyrin has received much attention as a potential alternative photosensitizer owing to its high optical, thermal and chemical stability as well as its strong absorption spectra of characteristic electron in the visible region. In order to optimize porphyrin molecular properties and then improve the photovoltaic properties of the dyesensitized solar cells (DSSCs) using porphyrin as the photosensitizer, porphyrin dyes are widely studied and designed by researchers at home and abroad. Results of the research works showed that carboxyl rather than other groups could well complete the electron transmission no matter whether it is connected on the meta position or the $\beta$-position of porphyrin. $^{4}$

\footnotetext{
*Author for correspondence (tjcugyl@126.com)
}

Although research works on the structure optimization of porphyrin have obtained considerable improvements, ${ }^{5,6}$ studies on the attaching technologies of the photosensitizer have not caused enough attentions, which lead to the limitation of further enhancing of the photoelectric conversion efficiencies of DSSC. At present, the sol-gel method and coating method are two normally used methods for the attaching of the photosensitizer. ${ }^{7-10}$ But these two methods have many disadvantages, for example, only physical bonding instead of chemical bonding can be established between the photosensitizer and $\mathrm{TiO}_{2}$, which causes the electron transmission resistance from photosensitizer to $\mathrm{TiO}_{2}$ increase. Furthermore, low binding force can lead to the break off of the coatings and further results in the shortening of the photosensitizer's service life. ${ }^{11}$ Moreover, photosensitizer coated outside $\mathrm{TiO}_{2}$ nano-grain will hinder the inner electron transmission to a certain extent. ${ }^{12}$

In general, high transmission resistance of electron from photosensitizer to $\mathrm{TiO}_{2}$ is the bottleneck for the further enhancement of photoelectric conversion efficiencies. This problem can be solved if an unblocked transmission channel of electron from photosensitizer to $\mathrm{TiO}_{2}$ can be established, and this is totally depended on the bonding mode between photosensitizer and $\mathrm{TiO}_{2}$. Hence in the present research works, $\mathrm{TiO}_{2}$ nanoporous films were firstly prepared by anodic oxidation. Based on which, attaching of the photosensitizer on the prepared $\mathrm{TiO}_{2}$ nanoporous films were conducted using a new mode by the electrochemical method. The photoelectrochemical properties of $\mathrm{TiO}_{2}$ nanoporous films attached with and without photosensitizer 5,10,15,20-tetra(4-carboxyphenyl) porphyrin (TCPP) were characterized and compared 
by fluorescence spectroscopy and electrochemical test. And effects of process parameters on the properties of $\mathrm{TiO}_{2}$ nanoporous films were also investigated.

\section{Experimental}

\subsection{Experimental chemicals and materials}

All the chemicals were of analytical grade and used asreceived. And all the solutions were prepared with redistilled water to ensure the stabilities of ions in the solution.

\subsection{Pre-treatment of metal Ti}

Before anodic oxidation, metal Ti needs to be pre-treated to remove the natural $\mathrm{TiO}_{2}$ film and grease on the Ti sheet. ${ }^{13}$ The experimental details are given as follows.

Briefly, Ti sheet with purity of $99.9 \%$ was cut into pieces with the size of $20 \times 20 \times 0.1 \mathrm{~mm}$. Then a certain kind of resin was used to seal the $\mathrm{Ti}$ sheet between two sheet glasses with only the reaction region $(15 \times 15 \mathrm{~mm})$ and the conductive part exposed outside (as shown in figure 1). Later, surface of the reaction region was cleaned by absorbent cotton immersed with acetone and rinsed with redistilled water. Then the sealed Ti specimen was immersed into $5 \%$ sodium hydroxide solution at $50^{\circ} \mathrm{C}$ for $5 \mathrm{~min}$ and $0.5 \%$ sulphuric acid solution and at room temperature for $10 \mathrm{~s}$, successively, while rinsing of the specimen with redistilled water was conducted after each step. Finally, electrochemical degreasing of the Ti specimen was carried out at room temperature in the degreasing solution using Pt and Ti sheets as anode and cathode, respectively. After rinsing the Ti specimen with redistilled water for the last time, the whole pretreatment of metal Ti was completed.

\subsection{Preparation of $\mathrm{TiO}_{2}$ nanoporous films by anodic oxidation}

After pre-treatment, Ti specimen was anodic oxidized in the $0.5 \mathrm{~mol} \mathrm{l}^{-1}$ sulphuric acid solution using a two-step voltage mode. Under this mode, a low potential (called as initial potential) was firstly applied on the electrode and leads to the rapid increase and sudden decline of the current density. When the current density decrease to the lowest value (a compact barrier layer was formed), a high potential (called as discharge potential) was applied immediately and the current

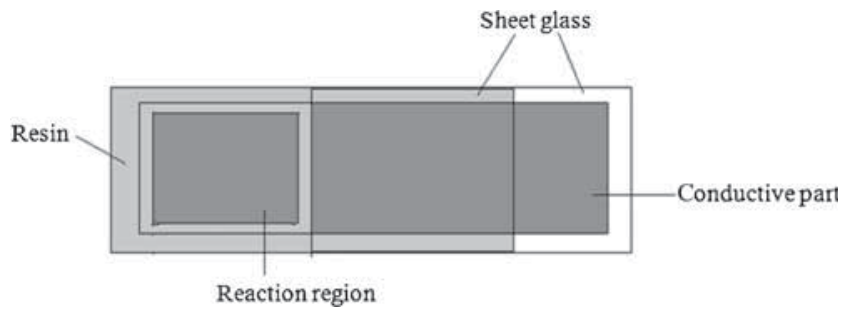

Figure 1. Schematic view of the metal Ti piece. density will rapidly increase and suddenly decline again (nanoporous were formed), and finally become stable. The potentials mentioned here are the potential difference between the anode and cathode, and 'initial potential-discharge potential' was used to express the applied oxidation potential value in this paper.

\subsection{Synthesis of photosensitizer TCPP}

A certain amount of 4-carboxybenzaldehyde, pyrrole, propionic acid were mixed and refluxed at $140^{\circ} \mathrm{C}$ for $4 \mathrm{~h}$. After cooling to room temperature, the mixture was added with ethanol, magnetic stirred and stored under room temperature overnight for crystallization. The precipitated crystal was collected by filtration and washed with methanol. Then a mixture of chloroform and acetone was added into the product, while mixture of tetrahydrofuran (THF) and acetic acid was used to elute the product. The synthesized product was analysed by infrared spectroscopy and ultraviolet spectroscopy and the results are shown in figures 2 and 3, respectively. By comparison of figure $2 \mathrm{a}$ with the peak value in literature (figure $2 b),{ }^{14}$ it can be found that the peak value of the synthesized product matches well with the literature value, which means that the synthesized product is indeed TCPP. Results shown in figure 2 further confirmed this conclusion.

\subsection{Attaching of photosensitizer TCPP on $\mathrm{TiO}_{2}$ nanoporous films}

Photosensitizer TCPP was attached on the prepared $\mathrm{TiO}_{2}$ nanoporous films by the electrochemical method through constant voltage mode. The electrolyte used for the attachment was a mixture of $\mathrm{H}_{2} \mathrm{SO}_{4}$ solution and $\mathrm{N}$, N-dimethylformamid (DMF) solution dissolved with TCPP. The electrolyte was prepared as follows: first, $1.6 \times 10^{-4} \mathrm{~g} \mathrm{ml}^{-1}$ TCPP DMF solution was prepared by dissolving $0.04 \mathrm{~g}$ TCPP in DMF and setting the volume to be $250 \mathrm{ml}$. Then the electrolyte could be obtained by mixing $100 \mathrm{ml}$ of 1.6 $\times 10^{-4} \mathrm{~g} \mathrm{ml}^{-1}$ TCPP DMF solution with $27.17 \mathrm{ml}$ of $98 \%$ $\mathrm{H}_{2} \mathrm{SO}_{4}$ solution and setting the volume to be $1000 \mathrm{ml}$. During the attaching process, working electrode (prepared $\mathrm{TiO}_{2}$ nanoporous films) and counter electrode ( $\mathrm{Ti}$ mesh covered with a layer of electrodeposited $\mathrm{Pt}$ ) were connected with the positive electrode and negative electrode of the electrical source, respectively.

\subsection{Characterization of the $\mathrm{TiO}_{2}$ thin films}

Electrochemical measurements were performed at ambient temperature using $\mathrm{CHI} 660 \mathrm{E}$ electrochemical working station (Huakeputian Instruments, Inc., Beijing). A standard threeelectrode cell (shown in figure 4), which consists of a prepared $\mathrm{TiO}_{2}$ film as the working electrode, a platinum plate as the auxiliary electrode, an aqueous $\mathrm{KCl}$ saturated calomel electrode (SCE) as the reference electrode and $0.25 \mathrm{~mol} \mathrm{l}^{-1} \mathrm{Na}_{2} \mathrm{SO}_{4}$ 


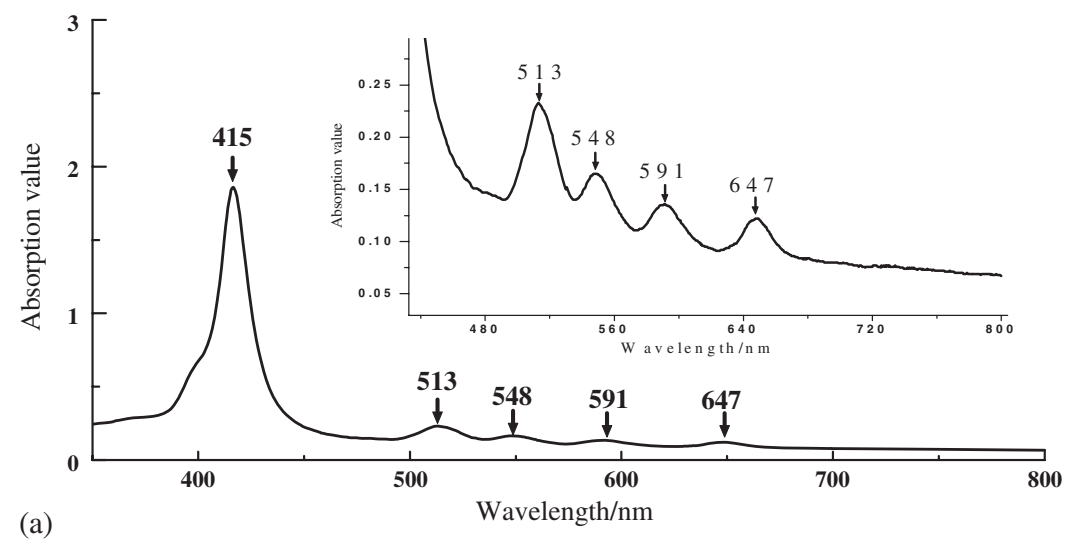

(a)

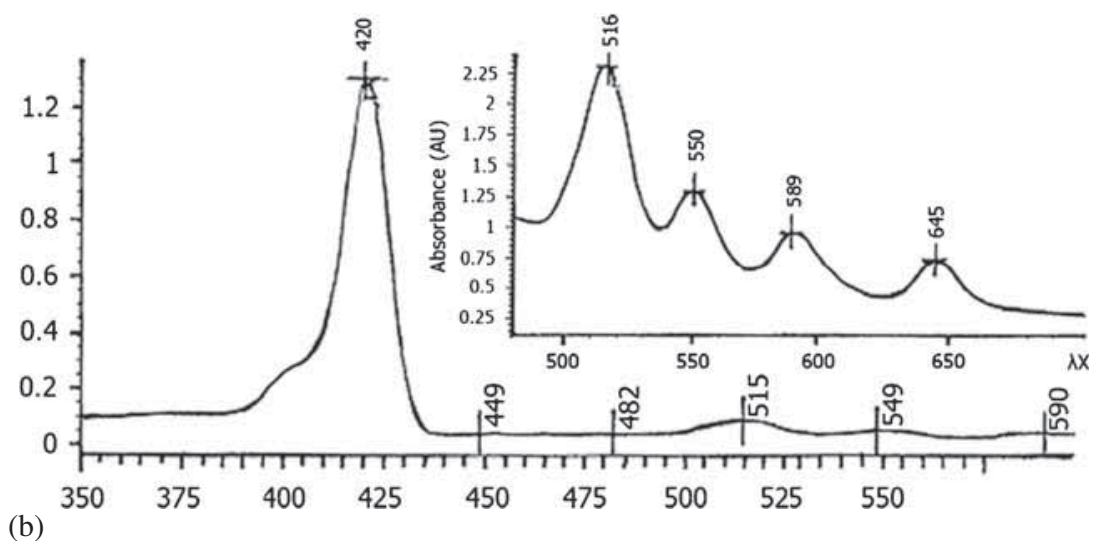

Figure 2. (a) UV-Vis absorption spectra of synthesized TCPP. (b) UV-Vis absorption spectra of TCPP in literature.

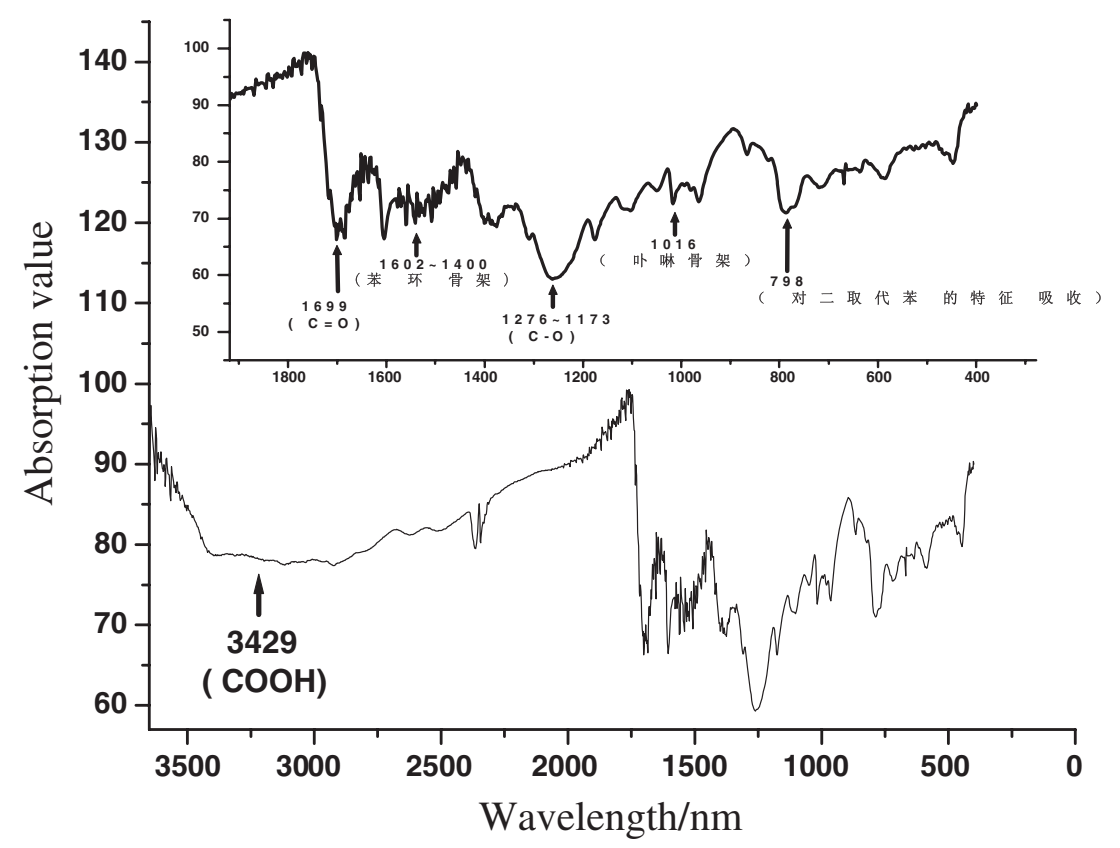

Figure 3. Infrared spectrum of synthesized TCPP.

solution as the electrolyte, was used for the electrochemical measurement. The working electrode was electrochemical degreased and rinsed with redistilled water in order to ensure a clean surface before the measurements. Solution was not stirred during all the electrochemical measurements. The three-electrode cell was placed into a photochemical reaction 


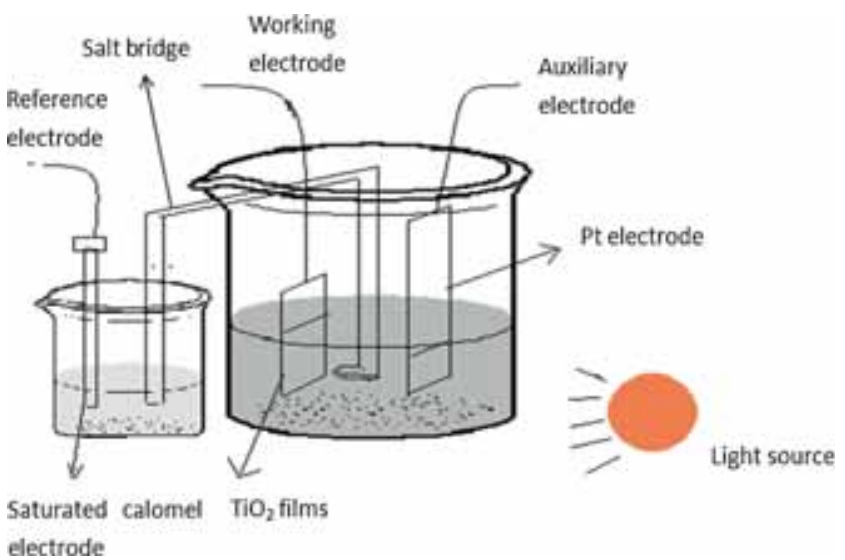

Figure 4. Schematic view of the three-electrode cell.

device (manufactured by Beijing NBET Technology Co., Ltd.) which contained a built-in Xenon lamp light source (Solar-500) simulating the solar light. The location of the three-electrode cell was adjusted to ensure that the light can vertically lay on the $\mathrm{TiO}_{2}$ films. The photoelectrochemical properties of the prepared $\mathrm{TiO}_{2}$ films were characterized by the open-circuit potential-time curves which were recorded alternately under the condition of lighting and darkness with the alternate time of $100 \mathrm{~s}$ and the total testing time of $600 \mathrm{~s}$.

The fluorescence spectra of the $\mathrm{TiO}_{2}$ films were obtained by fluorescence spectrophotometer (Jobin Yvon FL3-212Tcspc) in the wavelength range of $300-800 \mathrm{~nm}$ with the excitation wavelength of $370 \mathrm{~nm}$.

\section{Results and discussions}

\subsection{Photoelectrochemical properties of $\mathrm{TiO}_{2}$ nanoporous films}

3.1a Effects of oxidation potential on the photoelectrochemical properties of $\mathrm{TiO}_{2}$ nanoporous films: $\mathrm{TiO}_{2}$ nanoporous films were prepared under different oxidation potentials at $25^{\circ} \mathrm{C}$ in $0.5 \mathrm{~mol} \mathrm{l}^{-1} \mathrm{H}_{2} \mathrm{SO}_{4}$ solution with the oxidation time of $60 \mathrm{~min}$. The photoelectrochemical properties of the prepared $\mathrm{TiO}_{2}$ nanoporous films were characterized by the open-circuit potential-time curves under the condition of lighting and darkness. And the results are shown in figure 5 and table 1 .

It can be seen in figure 5 that the open-circuit potential changed obviously when the lighting condition alternates between lighting and darkness. Since lighting can promote the rapid separation of photogenerated electrons and holes which will successively diffuse to the interface between the electrode and solution, affect the electric double layer and further affect the open-circuit potential, change of the opencircuit potential under the condition of lighting and darkness can be used to evaluate the photoelectrochemical properties of the semiconductor materials. The more sensitive of the semiconductor materials to the light, the much bigger of $\Delta V$ can be observed.

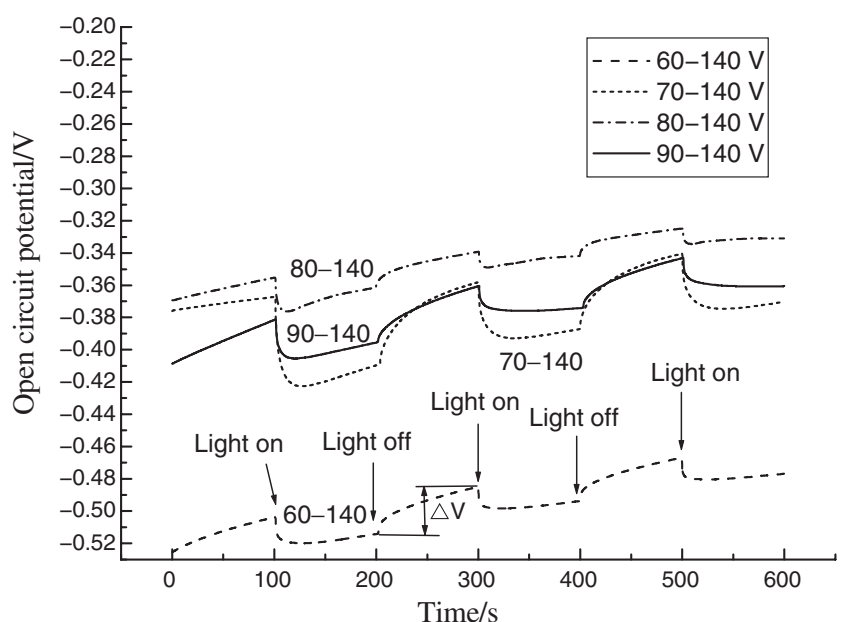

Figure 5. Open-circuit potential-time curves of $\mathrm{TiO}_{2}$ nanoporous films prepared under different oxidation potentials.

Table 1. $\Delta V$ comparisons of $\mathrm{TiO}_{2}$ nano-pore films prepared under different oxidation potentials.

\begin{tabular}{|c|c|c|c|c|}
\hline $\begin{array}{l}\text { Oxidation } \\
\text { potential (V) }\end{array}$ & $\begin{array}{c}\mathrm{H}_{2} \mathrm{SO}_{4} \\
\text { concentration } \\
\left(\mathrm{mol} \mathrm{l}^{-1}\right)\end{array}$ & $\begin{array}{l}\text { Oxidation } \\
\text { time } \\
(\min )\end{array}$ & $\begin{array}{c}\text { Oxidation } \\
\text { temperature } \\
\left({ }^{\circ} \mathrm{C}\right)\end{array}$ & $\Delta V(\mathrm{~V})$ \\
\hline 60-140 & 0.5 & 60 & 25 & 0.029 \\
\hline $70-140$ & 0.5 & 60 & 25 & 0.051 \\
\hline 80-140 & 0.5 & 60 & 25 & 0.023 \\
\hline 90-140 & 0.5 & 60 & 25 & 0.035 \\
\hline
\end{tabular}

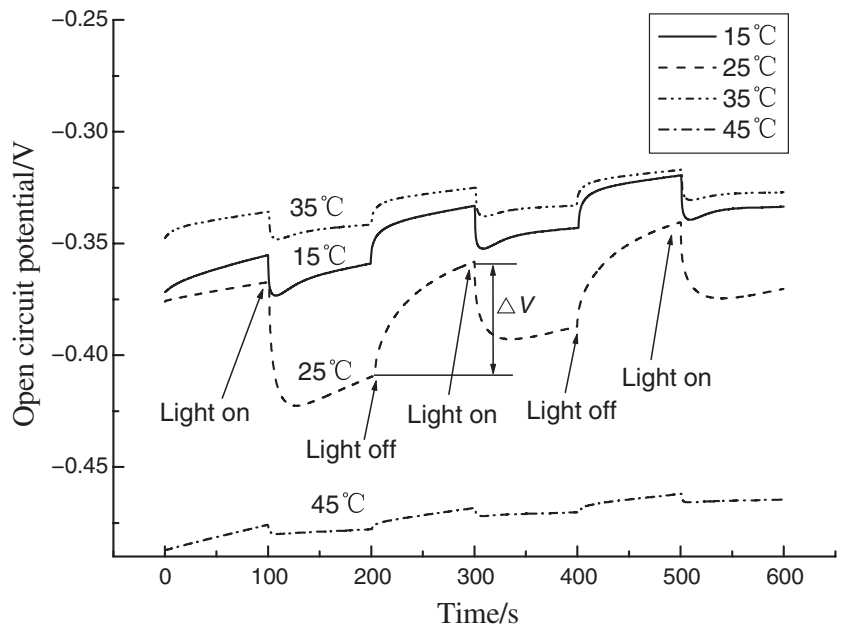

Figure 6. Open-circuit potential-time curves of $\mathrm{TiO}_{2}$ nanoporous films prepared at different oxidation temperatures.

It can be seen from figure 5 and table 1 that $\mathrm{TiO}_{2}$ nanoporous films prepared under 70-140 V show the highest $\Delta V$ value, which reveals that the $\mathrm{TiO}_{2}$ nanoporous films prepared under $70-140 \mathrm{~V}$ possess the best photoelectrochemical property. 
3.1b Effects of oxidation temperature on the photoelectrochemical properties of $\mathrm{TiO}_{2}$ nanoporous films: $\mathrm{TiO}_{2}$ nanoporous films were prepared at different oxidation temperatures under $70-140 \mathrm{~V}$ in $0.5 \mathrm{~mol}^{-1} \mathrm{H}_{2} \mathrm{SO}_{4}$ solution with the oxidation time of $60 \mathrm{~min}$. The photoelectrochemical properties of the prepared $\mathrm{TiO}_{2}$ nanoporous films were characterized by the open-circuit potential-time curves under the condition of lighting and darkness. And the results are shown in figure 6 and table 2 .

It can be seen from figure 6 and table 2 that $\mathrm{TiO}_{2}$ nanoporous films prepared at $25^{\circ} \mathrm{C}$ show the highest $\Delta V$ value, which reveals that the $\mathrm{TiO}_{2}$ nanoporous films prepared at $25^{\circ} \mathrm{C}$ possess the best photoelectrochemical property.

Table 2. $\Delta V$ comparisons of $\mathrm{TiO}_{2}$ nano-pore films prepared at different oxidation temperatures.

\begin{tabular}{lcccc}
\hline $\begin{array}{l}\text { Oxidation } \\
\text { temperature } \\
\left({ }^{\circ} \mathrm{C}\right)\end{array}$ & $\begin{array}{c}\mathrm{H}_{2} \mathrm{SO}_{4} \\
\text { concentration } \\
\left(\mathrm{mol} \mathrm{l}^{-1}\right)\end{array}$ & $\begin{array}{c}\text { Oxidation } \\
\text { potential }(\mathrm{V})\end{array}$ & $\begin{array}{c}\text { Oxidation } \\
\text { time (min) }\end{array}$ & $\Delta V(\mathrm{~V})$ \\
\hline 15 & 0.5 & $70-140$ & 60 & 0.026 \\
25 & 0.5 & $70-140$ & 60 & 0.051 \\
35 & 0.5 & $70-140$ & 60 & 0.017 \\
45 & 0.5 & $70-140$ & 60 & 0.010 \\
\hline
\end{tabular}

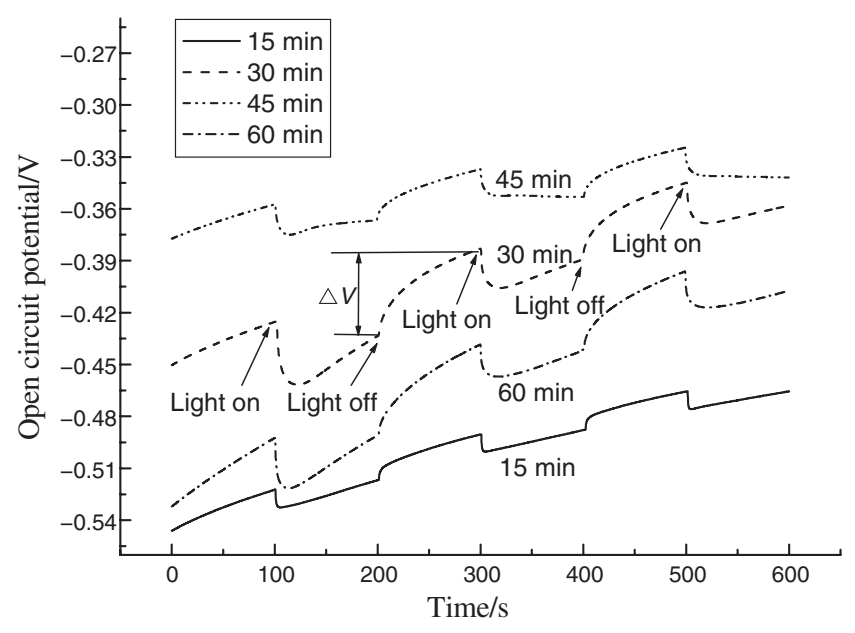

Figure 7. Open-circuit potential-time curves of $\mathrm{TiO}_{2}$ nanoporous films prepared under different oxidation times.

Table 3. $\Delta V$ comparisons of $\mathrm{TiO}_{2}$ nano-pore films prepared under different oxidation times.

\begin{tabular}{lcccc}
\hline $\begin{array}{l}\text { Oxidation } \\
\text { time (min) }\end{array}$ & $\begin{array}{c}\text { Oxidation } \\
\text { potential } \\
(\mathrm{V})\end{array}$ & $\begin{array}{c}\mathrm{H}_{2} \mathrm{SO}_{4} \\
\text { concentration } \\
\left(\mathrm{mol} \mathrm{l}^{-1}\right)\end{array}$ & $\begin{array}{c}\text { Oxidation } \\
\text { temperature } \\
\left({ }^{\circ} \mathrm{C}\right)\end{array}$ & $\Delta V(\mathrm{~V})$ \\
\hline 15 & $70-140$ & 0.5 & 25 & 0.026 \\
30 & $70-140$ & 0.5 & 25 & 0.051 \\
45 & $70-140$ & 0.5 & 25 & 0.028 \\
60 & $70-140$ & 0.5 & 25 & 0.053 \\
\hline
\end{tabular}

3.1c Effects of oxidation time on the photoelectrochemical properties of $\mathrm{TiO}_{2}$ nanoporous films: $\mathrm{TiO}_{2}$ nanoporous films were prepared with different oxidation times under $70-140 \mathrm{~V}$ in $0.5 \mathrm{~mol} \mathrm{l}^{-1} \mathrm{H}_{2} \mathrm{SO}_{4}$ solution at $25^{\circ} \mathrm{C}$. The photoelectrochemical properties of the prepared $\mathrm{TiO}_{2}$ nanoporous films were characterized by the open-circuit potential-time curves under the condition of lighting and darkness. And the results are shown in figure 7 and table 3 .

It can be seen from figure 7 and table 3 that $\mathrm{TiO}_{2}$ nanoporous films prepared with the oxidation time of 60 min show the highest $\Delta V$ value, which reveals that the $\mathrm{TiO}_{2}$ nanoporous films prepared with the oxidation time of $60 \mathrm{~min}$ possess the best photoelectrochemical property.

Based on the above analysis, it can be concluded that the optimized process parameters for the preparation of $\mathrm{TiO}_{2}$ nanoporous films with the best photoelectrochemical property are as follows: oxidation potentials is 70-140 V, oxidation temperature is $25^{\circ} \mathrm{C}, \mathrm{H}_{2} \mathrm{SO}_{4}$ electrolyte concentration is $0.5 \mathrm{~mol} \mathrm{l}^{-1}$ and oxidation time is $60 \mathrm{~min}$.

\subsection{Photoelectrochemical properties of TCPP-attached $\mathrm{TiO}_{2}$ nanoporous films}

As mentioned above, attachment of photosensitizer TCPP can improve the photoelectrochemical properties of $\mathrm{TiO}_{2}$ nanoporous films. But the traditional attaching methods have many disadvantages, such as poor physical bonding between the photosensitizer and $\mathrm{TiO}_{2}$, which leads to the high electron transmission resistance from photosensitizer to $\mathrm{TiO}_{2}$ and limits the improvement of the photoelectrochemical properties of $\mathrm{TiO}_{2}$ nanoporous films. Hence in the present work a method which made the TCPP attachment realized through the electrochemical technique was proposed. Using this method, the attaching process was conducted on anode under an electric field environment in the electrolyte containing TCPP. Since TCPP possesses negative charge, it will move to the anode under the electric field and enrich

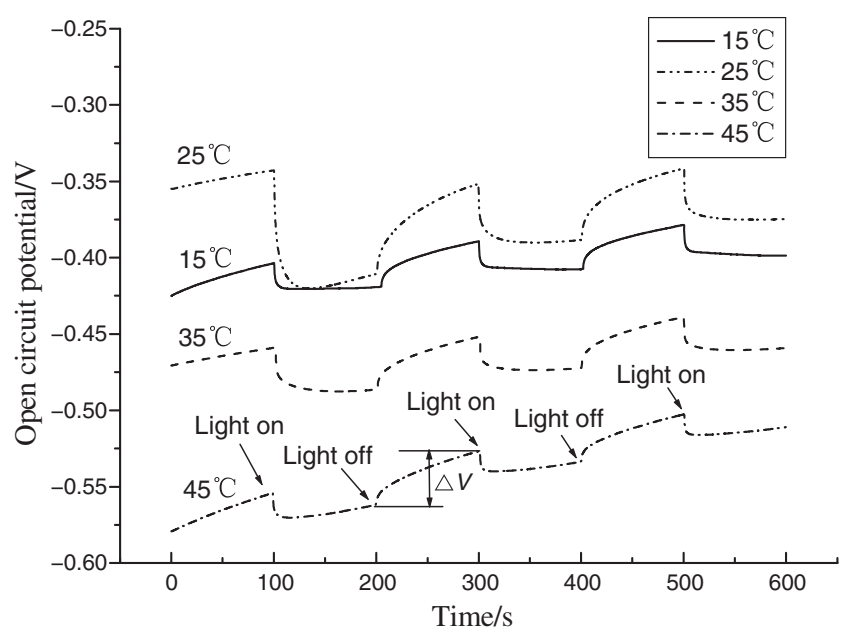

Figure 8. Open-circuit potential-time curves of TCPP-attached $\mathrm{TiO}_{2}$ nanoporous films prepared at different attaching temperatures. 
near the anode. Furthermore, the previous research ${ }^{15}$ indicated that the $\mathrm{TiO}_{2}$ nanoporous films prepared by electrochemical oxidation showed anatase crystals which contained large amount of hydroxyl on its surface. Hence when TCPP with negative charge transfers to the anode region, chemical bonding will occur between the carboxyl on TCPP and the hydroxyl on $\mathrm{TiO}_{2}$ nanoporous films to form ester bond. This bonding is much more stable and beneficial to establish an unblocked transmission channel of electron from photosensitizer to $\mathrm{TiO}_{2}$. All of these can reduce the electron transmission resistance from photosensitizer to $\mathrm{TiO}_{2}$ and

Table 4. $\Delta V$ comparisons of $\mathrm{TCPP}$-attached $\mathrm{TiO}_{2}$ nano-pore films prepared at different attaching temperatures.

\begin{tabular}{lcccc}
\hline $\begin{array}{l}\text { Attaching } \\
\text { temperature }\left({ }^{\circ} \mathrm{C}\right)\end{array}$ & $\begin{array}{c}\text { Oxidation } \\
\text { potential }(\mathrm{V})\end{array}$ & $\begin{array}{c}\text { Attaching } \\
\text { time }(\mathrm{min})\end{array}$ & $\begin{array}{c}\text { Attaching } \\
\text { voltage }(\mathrm{V})\end{array}$ & $\Delta V(\mathrm{~V})$ \\
\hline 15 & $70-140$ & 60 & 40 & 0.0299 \\
25 & $70-140$ & 60 & 40 & 0.0591 \\
35 & $70-140$ & 60 & 40 & 0.0345 \\
45 & $70-140$ & 60 & 40 & 0.0346 \\
\hline
\end{tabular}
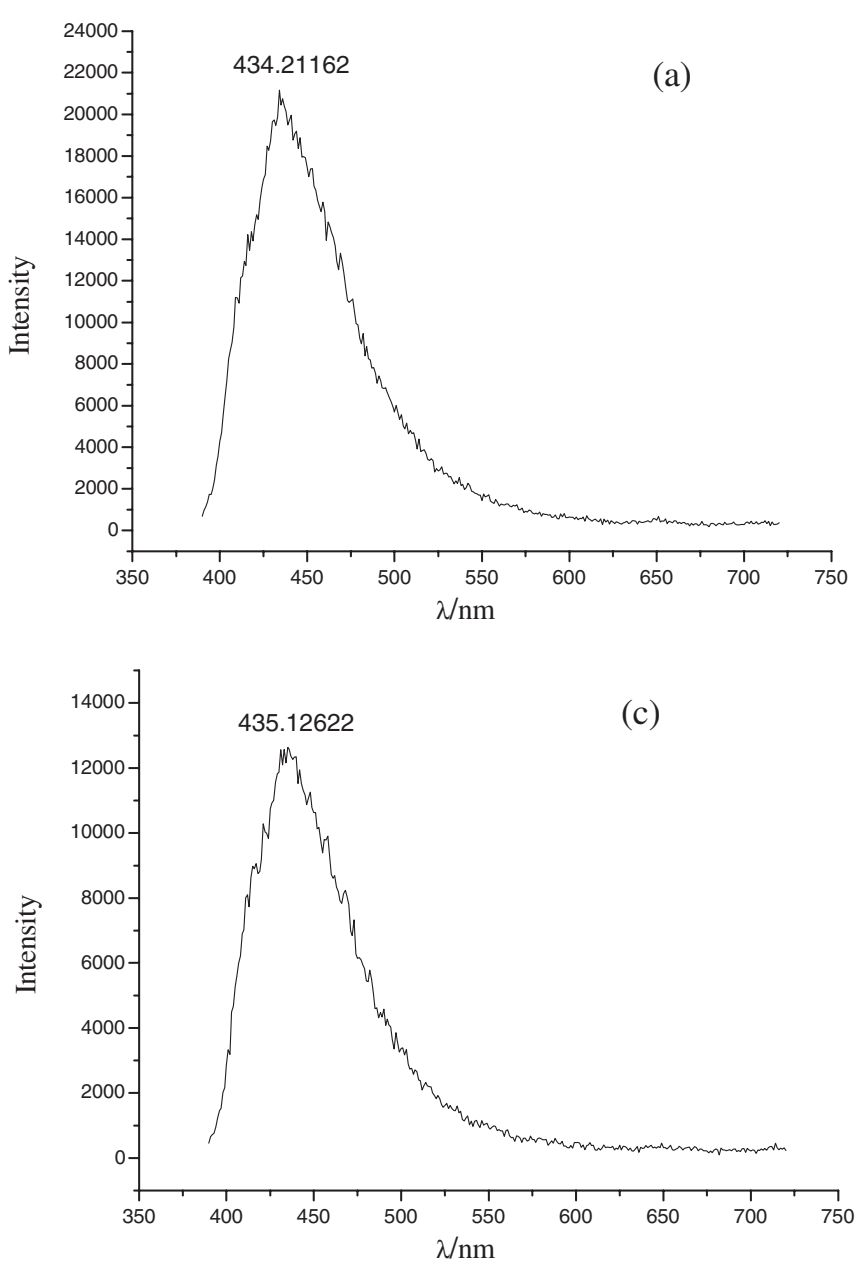

finally bring the obvious improvement of the photoelectrochemical properties of $\mathrm{TiO}_{2}$ nanoporous films.

In order to certify the effects of our method, attaching of the photosensitizer TCPP on the prepared $\mathrm{TiO}_{2}$ nanoporous films was performed using the electrochemical technique and the effects of the attaching process parameters on the properties of TCPP-attached $\mathrm{TiO}_{2}$ nanoporous films were also investigated.

3.2a Effects of attaching temperature on the photoelectrochemical properties of TCPP-attached $\mathrm{TiO}_{2}$ nanoporous films: $\mathrm{TiO}_{2}$ nanoporous films were firstly prepared under $70-140 \mathrm{~V}$ in $0.5 \mathrm{~mol} \mathrm{l}^{-1} \mathrm{H}_{2} \mathrm{SO}_{4}$ solution at $25^{\circ} \mathrm{C}$ with the oxidation time of $60 \mathrm{~min}$, which are the optimized process parameters for the preparation of $\mathrm{TiO}_{2}$ nanoporous films according to the above research. And then attaching of TCPP on the prepared $\mathrm{TiO}_{2}$ nanoporous films were conducted under $40 \mathrm{~V}$ for $60 \mathrm{~min}$ at different temperatures. The obtained TCPP-attached $\mathrm{TiO}_{2}$ nanoporous films were characterized by the open-circuit potential-time curves under the condition of lighting and darkness. And the results are shown in figure 8 and table 4.
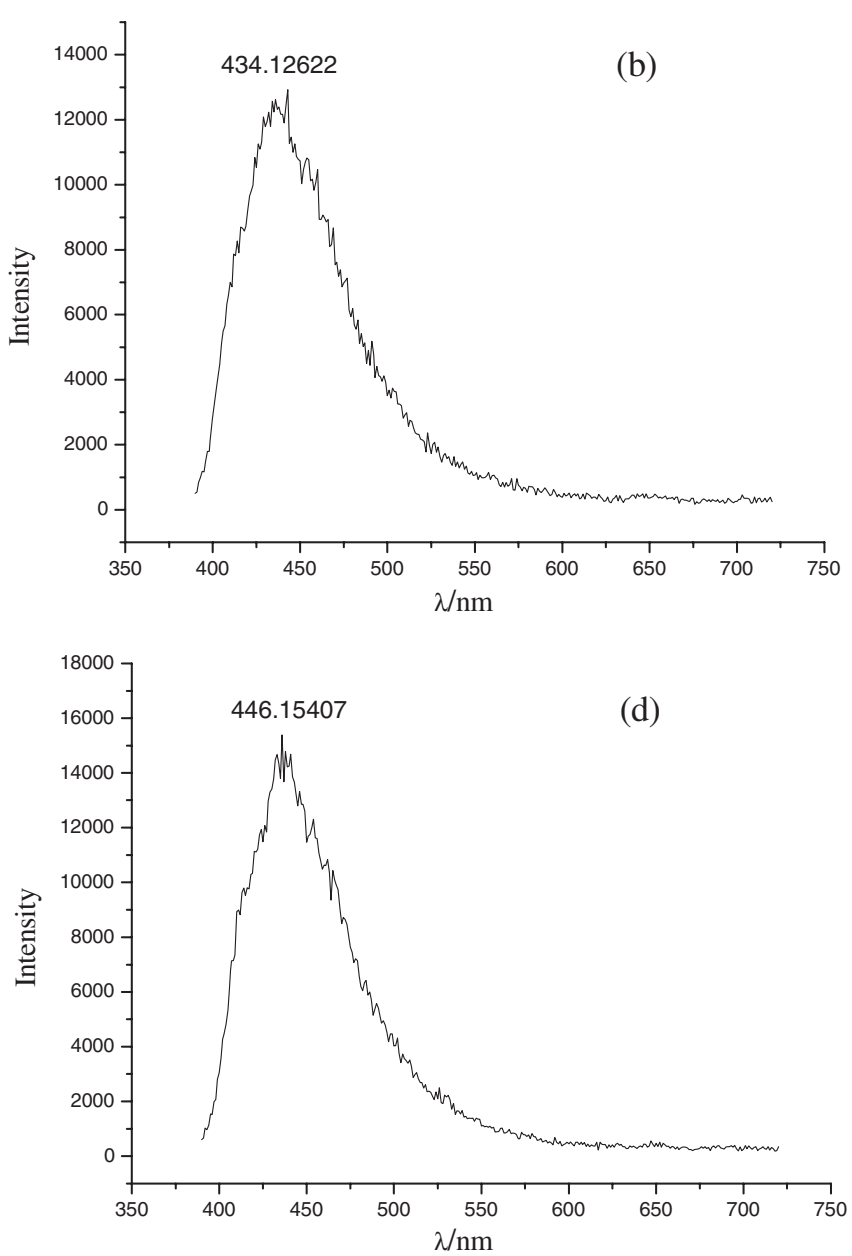

Figure 9. Fluorescence spectroscopy of $\mathrm{TCPP}$-attached $\mathrm{TiO}_{2}$ nanoporous films prepared at different attaching temperatures: $(\mathbf{a}) 15^{\circ} \mathrm{C}$, (b) $25^{\circ} \mathrm{C}$, (c) $35^{\circ} \mathrm{C}$ and (d) $45^{\circ} \mathrm{C}$. 
Table 5. Peak intensity and location of the fluorescence spectroscopy in figure 9.

\begin{tabular}{lcc}
\hline $\begin{array}{l}\text { Attaching electrolyte } \\
\text { temperature }\left({ }^{\circ} \mathrm{C}\right)\end{array}$ & $\begin{array}{c}\text { Peak location } \\
(\mathrm{nm})\end{array}$ & $\begin{array}{c}\text { Peak } \\
\text { intensity }\end{array}$ \\
\hline 15 & 434 & 12,622 \\
25 & 434 & 21,162 \\
35 & 436 & 15,407 \\
45 & 435 & 12,622 \\
\hline
\end{tabular}

It can be seen from figure 8 and table 4 that TCPP-attached $\mathrm{TiO}_{2}$ nanoporous films prepared in the electrolyte at $25^{\circ} \mathrm{C}$ show the highest $\Delta V$ value, which reveals that the TCPPattached $\mathrm{TiO}_{2}$ nanoporous films obtained in the electrolyte at $25^{\circ} \mathrm{C}$ possess the best photoelectrochemical property.

The obtained TCPP-attached $\mathrm{TiO}_{2}$ nanoporous films were also characterized by fluorescence spectroscopy. And the corresponding results are shown in figure 9 and table 5 . According to the fluorescence emission principle, free electron will transit from the ground state or the low-energy state to the excited state or the high-energy state and then transits back and send out radiation with the same or different wavelength to the original radiation after it absorbs radiation with characteristic wavelength. The peak intensity in the fluorescence spectroscopy can be used to evaluate the attaching effect of photosensitizer TCPP, i.e., photoelectrochemical properties of the TCPP-attached $\mathrm{TiO}_{2}$ nanoporous films. The more amount of TCPP attached on the $\mathrm{TiO}_{2}$ nanoporous films, the more sensitive of the semiconductor materials to the light and certainly the much higher of the peak intensity can be observed.

It can be seen from figure 9 and table 5 that TCPP-attached $\mathrm{TiO}_{2}$ nanoporous films prepared in the attaching electrolyte at $25^{\circ} \mathrm{C}$ show the highest peak intensity value, which reveals that the TCPP-attached $\mathrm{TiO}_{2}$ nanoporous films obtained at $25^{\circ} \mathrm{C}$ possess the best photoelectrochemical property. This conclusion matched well with that obtained by open-circuit potential-time curves in figure 8 and table 4 .

3.2b Effects of attaching voltage on the photoelectrochemical properties of TCPP-attached $\mathrm{TiO}_{2}$ nanoporous films: $\mathrm{TiO}_{2}$ nanoporous films were prepared under $70-140 \mathrm{~V}$ in $0.5 \mathrm{~mol} \mathrm{l}^{-1} \mathrm{H}_{2} \mathrm{SO}_{4}$ solution at $25^{\circ} \mathrm{C}$ with the oxidation time of $60 \mathrm{~min}$. And then attaching of TCPP on the prepared $\mathrm{TiO}_{2}$ nanoporous films were conducted in the attaching electrolyte for $60 \mathrm{~min}$ at $25^{\circ} \mathrm{C}$ but under different attaching voltages. The obtained TCPP-attached $\mathrm{TiO}_{2}$ nanoporous films were characterized by the open-circuit potential-time curves under the condition of lighting and darkness. And the results are shown in figure 10 and table 6 .

It can be seen from figure 10 and table 6 that TCPPattached $\mathrm{TiO}_{2}$ nanoporous films prepared under the attaching voltage of $60 \mathrm{~V}$ show the highest $\Delta V$ value, which reveals that the TCPP-attached $\mathrm{TiO}_{2}$ nanoporous films obtained at this voltage possess the best photoelectrochemical property.

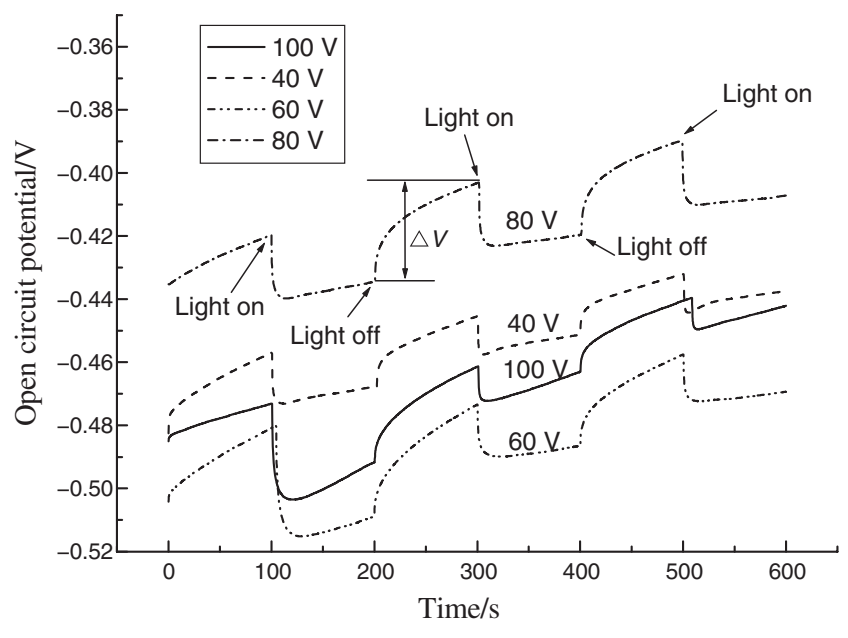

Figure 10. Open-circuit potential-time curves of TCPP-attached $\mathrm{TiO}_{2}$ nanoporous films prepared under different attaching voltages.

Table 6. $\Delta V$ comparisons of TCPP-attached $\mathrm{TiO}_{2}$ nano-pore films prepared under different attaching voltages.

Attaching Attaching Attaching electrolyte Oxidation voltage (V) time (min) temperature $\left({ }^{\circ} \mathrm{C}\right) \quad$ potential $(\mathrm{V}) \Delta V(\mathrm{~V})$

\begin{tabular}{rllll}
\hline 40 & 60 & 25 & $70-140$ & 0.0222 \\
60 & 60 & 25 & $70-140$ & 0.0353 \\
80 & 60 & 25 & $70-140$ & 0.0314 \\
100 & 60 & 25 & $70-140$ & 0.0302 \\
\hline
\end{tabular}

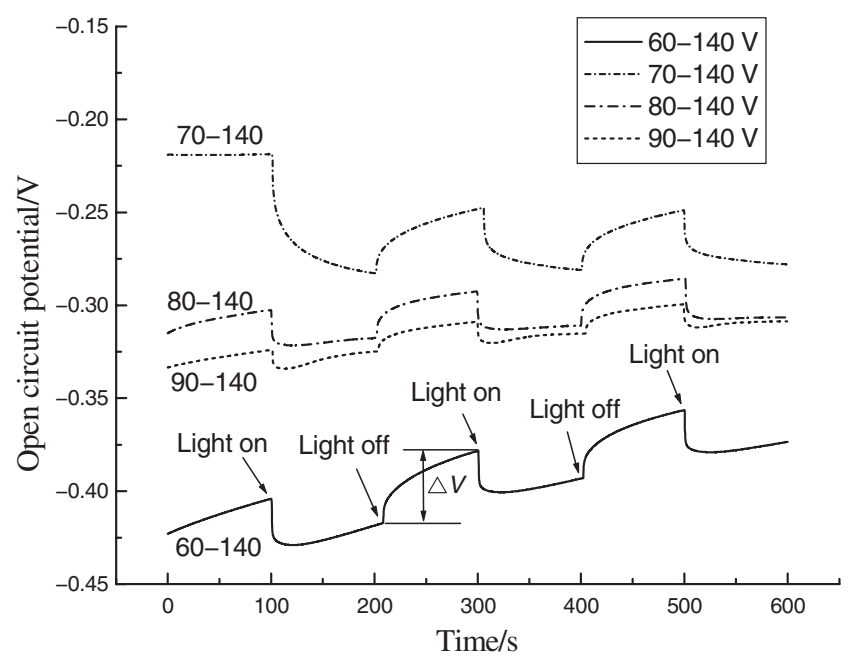

Figure 11. Open-circuit potential-time curves of TCPP-attached $\mathrm{TiO}_{2}$ nanoporous films prepared under different oxidation potentials.

3.2c Effects of oxidation potential on the photoelectrochemical properties of TCPP-attached $\mathrm{TiO}_{2}$ nanoporous films: $\mathrm{TiO}_{2}$ nanoporous films were prepared under different oxidation potentials at $25^{\circ} \mathrm{C}$ in $0.5 \mathrm{~mol}^{-1} \mathrm{H}_{2} \mathrm{SO}_{4}$ solution with the oxidation time of $60 \mathrm{~min}$. And then attaching 
of TCPP on the prepared $\mathrm{TiO}_{2}$ nanoporous films were conducted in the attaching electrolyte for $60 \mathrm{~min}$ at $25^{\circ} \mathrm{C}$ and under the voltage of $60 \mathrm{~V}$. The photoelectrochemical properties of the prepared TCPP-attached $\mathrm{TiO}_{2}$ nanoporous films were characterized by the open-circuit potential-time curves under the condition of lighting and darkness. And the results are shown in figure 11 and table 7.

It can be seen from figure 11 and table 7 that TCPPattached $\mathrm{TiO}_{2}$ nanoporous films prepared under the oxidation

Table 7. $\Delta V$ comparisons of $\mathrm{TCPP}$-attached $\mathrm{TiO}_{2}$ nano-pore films prepared under different oxidation potentials.

\section{Oxidation Attaching Attaching}

potential voltage electrolyte temperature Attaching

$\begin{array}{llll}(\mathrm{V}) & (\mathrm{V}) & \left({ }^{\circ} \mathrm{C}\right) & \text { time }(\mathrm{min})\end{array}$

\begin{tabular}{lllll}
\hline $60-140$ & 60 & 25 & 60 & 0.040 \\
$70-140$ & 60 & 25 & 60 & 0.064 \\
$80-140$ & 60 & 25 & 60 & 0.025 \\
$90-140$ & 60 & 25 & 60 & 0.016 \\
\hline
\end{tabular}
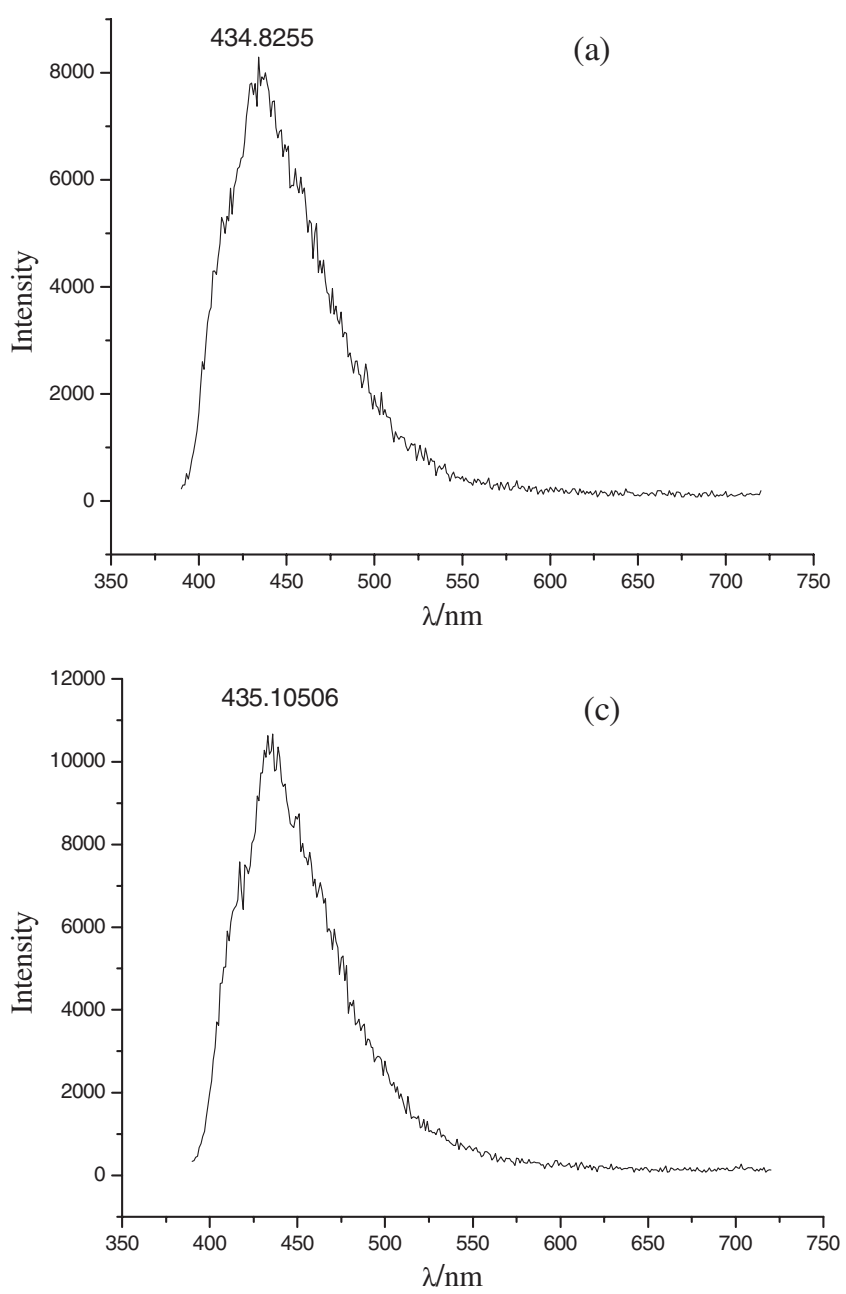

potentials of $70-140 \mathrm{~V}$ show the highest $\Delta V$ value, which reveals that the TCPP-attached $\mathrm{TiO}_{2}$ nanoporous films obtained under this oxidation potential possess the best photoelectrochemical property.

The obtained $\mathrm{TiO}_{2}$ nanoporous films attached with or without TCPP were also characterized by fluorescence spectroscopy. And the corresponding results are shown in figures 12,13 and table 8 .

It can be seen from figures 12,13 and table 8 that the peak intensity of $\mathrm{TiO}_{2}$ nanoporous films attached without TCPP are in the range of 7000-10000 while those of the $\mathrm{TiO}_{2}$ nanoporous films attached with TCPP are in the range of 15,000-24,000. Enhancement of the peak intensity can be observed in the fluorescence spectroscopy of all the samples prepared under different oxidation potentials after the $\mathrm{TiO}_{2}$ nanoporous films were sensitized with TCPP. This indicates that attaching of the photosensitizer TCPP indeed improves the properties of the $\mathrm{TiO}_{2}$ nanoporous films. It can also be found that TCPP-attached $\mathrm{TiO}_{2}$ nanoporous films prepared under the oxidation potentials of 70-140 V show the highest peak intensity value, which reveals that the TCPP-attached
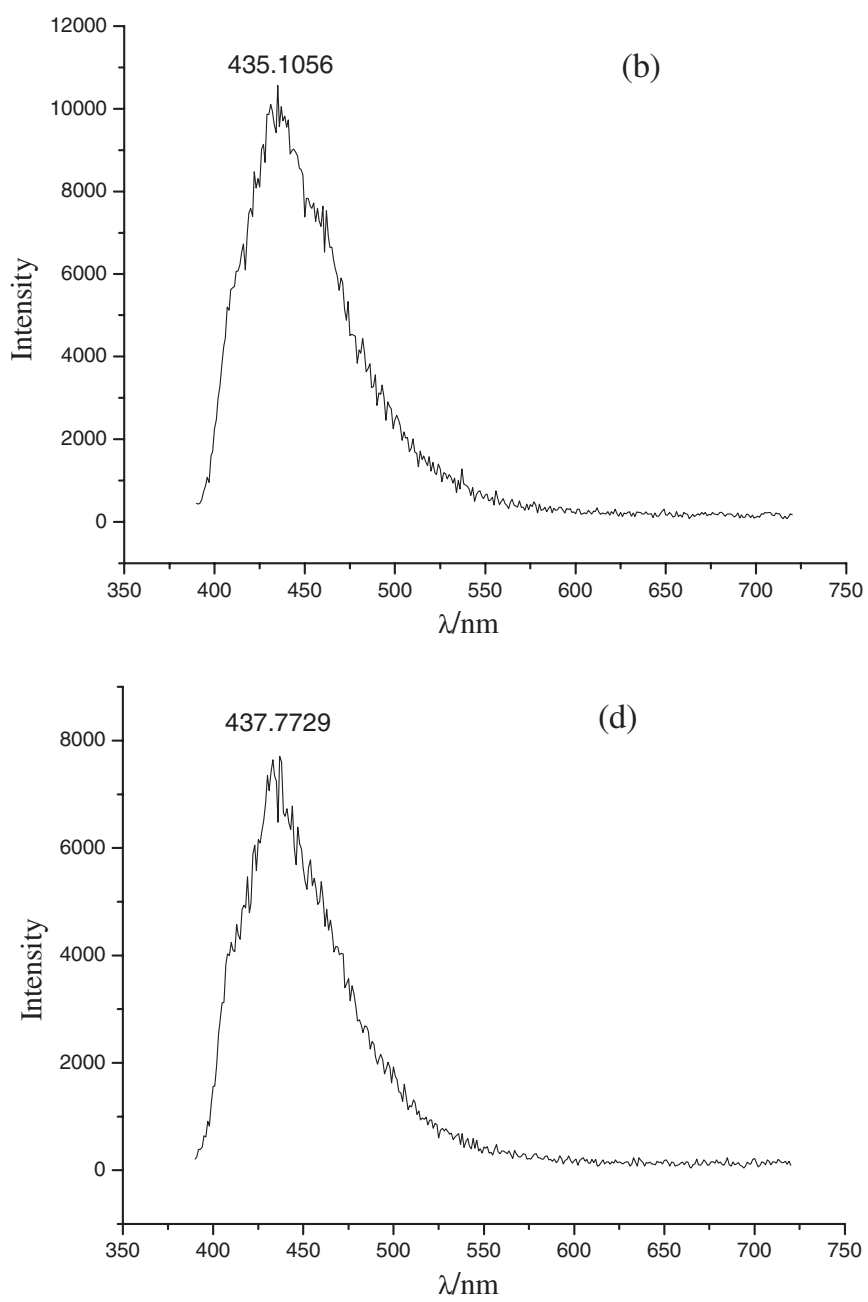

Figure 12. Fluorescence spectroscopy of $\mathrm{TiO}_{2}$ nanoporous films prepared under different oxidation potentials: (a) 60-140 V, (b) 70-140 V, (c) $80-140 \mathrm{~V}$ and (d) $90-140 \mathrm{~V}$. 

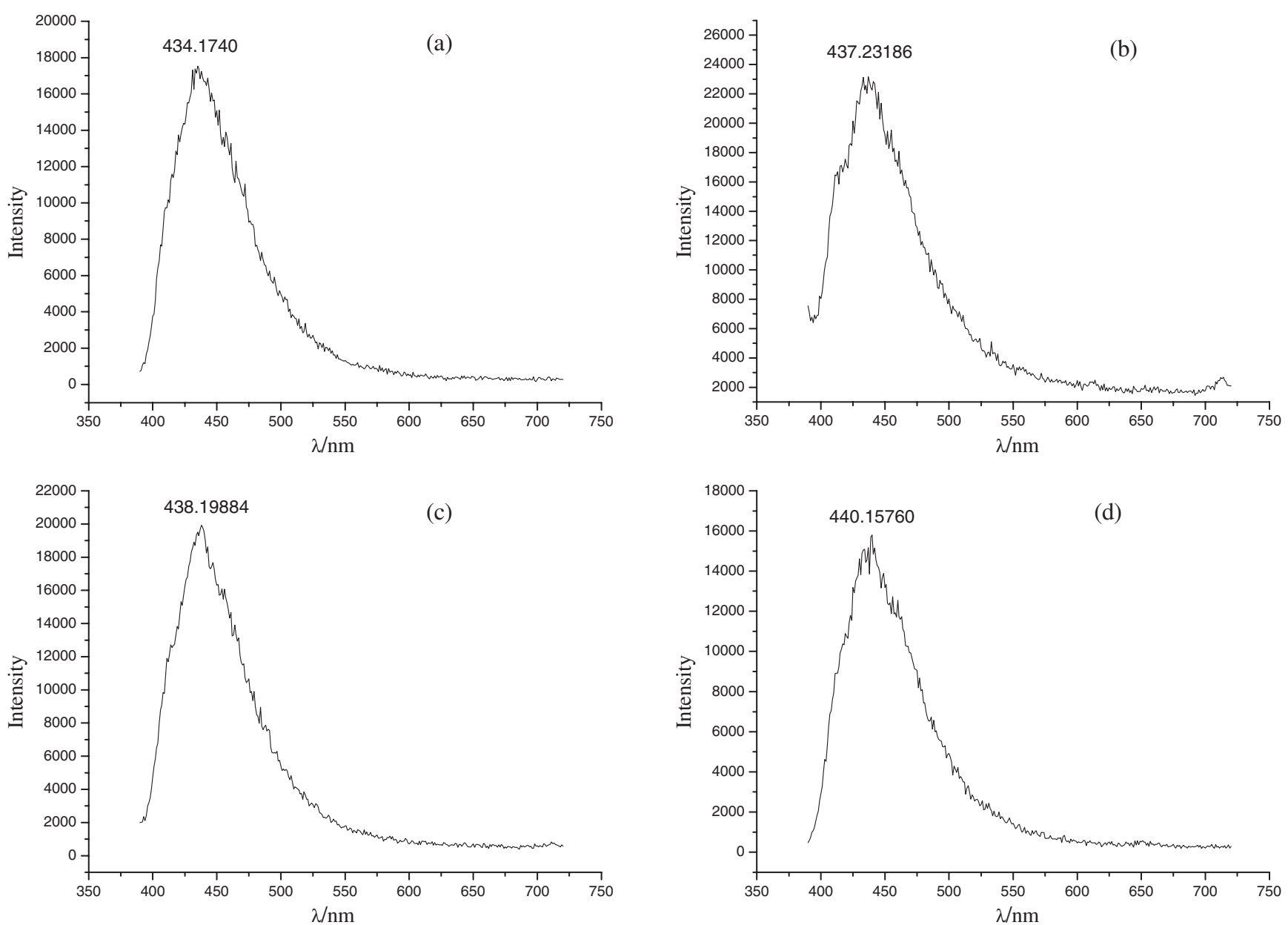

Figure 13. Fluorescence spectroscopy of TCPP-attached $\mathrm{TiO}_{2}$ nanoporous films prepared under different oxidation potentials: (a) 60-140 V, (b) 70-140 V, (c) 80-140 V and (d) 90-140 V.

Table 8. Peak intensity and location of the fluorescence spectroscopys in figures 12 and 13 .

\begin{tabular}{lccccc}
\hline & \multicolumn{2}{c}{$\mathrm{TiO}_{2}$ nano-pore films } & & \multicolumn{2}{c}{ TCPP-attached $\mathrm{TiO}_{2}$ nano-pore films } \\
\cline { 2 - 3 } \cline { 5 - 6 } Oxidation potential (V) & Peak location $(\mathrm{nm})$ & Peak intensity & & Peak location (nm) & Peak intensity \\
\hline $60-140$ & 434 & 8225 & & 434 & 17,409 \\
$70-140$ & 435 & 10,564 & & 437 & 23,186 \\
$80-140$ & 435 & 10,506 & & 438 & 19,884 \\
$90-140$ & 437 & 7729 & & 440 & 15,760 \\
\hline
\end{tabular}

$\mathrm{TiO}_{2}$ nanoporous films obtained under this oxidation potential possess the best photoelectrochemical property. And this conclusion matches well with that obtained by opencircuit potential-time curves in figure 11 and table 7 .

\section{Conclusions}

In this paper, $\mathrm{TiO}_{2}$ nanoporous films were prepared by anodic oxidation using two-step voltage mode while the constant voltage electrochemical method was used to attach of photosensitizer TCPP on the prepared $\mathrm{TiO}_{2}$ nanoporous films. Properties of $\mathrm{TiO}_{2}$ nanoporous films attached with and without photosensitizer TCPP were analysed by electrochemical test and fluorescence spectroscopy and the effects of process parameters on the properties of $\mathrm{TiO}_{2}$ nanoporous films were also investigated. The results show that the optimized process parameters for the preparation of $\mathrm{TiO}_{2}$ nanoporous films with the best photoelectrochemical property are as follows: oxidation potential is $70-140 \mathrm{~V}$, oxidation temperature is $25^{\circ} \mathrm{C}, \mathrm{H}_{2} \mathrm{SO}_{4}$ electrolyte concentration is $0.5 \mathrm{~mol}^{-1}$ and oxidation time is $60 \mathrm{~min}$. Attaching of TCPP on the $\mathrm{TiO}_{2}$ nanoporous films can indeed improve the properties of $\mathrm{TiO}_{2}$ nanoporous films, and the optimized attaching electrolyte temperature and attaching voltage are $25^{\circ} \mathrm{C}$ and $60 \mathrm{~V}$, respectively. 


\section{Acknowledgements}

This work was attached by the National Training Programs of Innovation and Entrepreneurship for Undergraduates (201410069022), Tianjin University of Commerce Training Programs of Innovation and Entrepreneurship for Undergraduates (2014090) and National Science Foundation of China (11272231).

\section{References}

1. Chen J K, Fu W Y, Yuan G Y, Runa A, Bala Hari, Wang X D, Sun G, Cao J L and Zhang Z Y 2014 Mater. Lett. 135229

2. Zhao Z Y, Zhou Y, Wan W C, Wang F, Zhang Q and Lin Y H 2014 Mater. Lett. 130150

3. Palmas S, Pozzo A D, Mascia M, Vacca A, Ardu A, Matarrese $\mathrm{R}$ and Nova I 2011 Int. J. Hydrogen Energy 368894

4. Ma T, Inoue K, Noma H, Yao K and Abe E 2002 J. Photochem. Photobiol. A. 152207

5. Imahori $\mathrm{H}$, Iijima $\mathrm{H}$, Hayashi $\mathrm{H}$, Toude $\mathrm{Y}$, Umeyama $\mathrm{T}$, Matano Y and Ito S 2011 ChemSusChem 4797
6. Imahori H, Kang S, Hayashi H, Haruta M, Kurata H, Isoda S, Canton S E, Infahsaeng Y, Kathiravan A, Pascher T, Chábera P, Yartsev A P and Sundström V 2011 J. Phys. Chem. A 115 3679

7. Li Z H, Zhou X D, Wang D J, Zou X, Wang Y N and Zou G T 2007 Chem. Res. Chin. Univ. 281151

8. Pan K, Liu Z Y, Xu J J, Yu M, Wang D J, Bai Y B and Li T J 2004 Chem. Res. Chin. Univ. 25934

9. Wang C, Yang G M, Li J, Mele G, Słota R, Broda M A, Duan M Y, Vasapollo G, Zhang X F and Zhang F X 2009 Dyes Pigm. 80321

10. Meen T H, Water W, Chen W R, Chao S M, Ji L W and Huang C J 2009 J. Phys. Chem. Solids 70472

11. Warnan J, Favereau L, Pellegrin Y, Blart E, Jacquemin D and Odobel F 2011 J. Photochem. Photobiol. A 2269

12. Sule E E and Gulsah T 2011 Renew. Energy 361821

13. Gong Y L, Ren Y X, Yang Y, Bai Z C and Guo H T 2007 J. Chem. Ind. Eng. (China) 123185

14. Buntem R, Intasiri A and Lueangchaichaweng W $2010 \mathrm{~J}$. Colloid Interface Sci. 3478

15. Gong Y L, Li F H, Bai Z C and Yang Y 2010 Mater. Prot. (China) $\mathbf{4 3} 37$ 